\title{
KEEPING THE BODY IMMUNE IN ISLAMIC PERSPECTIVE IN PANDEMIC TIMES
}

\author{
Samsuddin ${ }^{1 *}$, Misbahuddin ${ }^{2}$, Hamka $^{3}$, Ardi $^{4}$ \\ ${ }^{1}$ Department of Aqeedah and Islamic philosophy, Institut Agama Islam As'adiyah Sengkang \\ Lapongkoda Wajo, South Sulawesi, Indonesia. 90914 \\ *Email: samsuddin8508@gmail.com \\ 2Department of Da'wah Management, Faculty of Da'wah and Communication, \\ UIN Alauddin Makassar \\ Sultan Alauddin Street No. 63 Gowa, South Sulawesi, Indonesia. 92113 \\ Email: misbahuddin08121970@gmail.com \\ ${ }^{3}$ Department of Islamic Criminal Law, Faculty of Economics and Islamic Law \\ Institut Agama Islam Muhammadiyah Sinjai \\ Sultan Hasanudin Street No.20 Sinjai, South Sulawesi, Indonesia. 92614 \\ Email: hamkaadolc@gmail.com \\ ${ }^{4}$ Faculty of Islamic Religion, Universitas Muslim Indonesia \\ Urip Sumoharjo Street Makassar, South Sulawesi, Indonesia. 90231 \\ Email: ardi.fai@umi.ac.id
}

\begin{abstract}
This research is about maintaining the body's immunity from an islamic perspective during a pandemic. Health is a very attentive thing in Islam, so Islam recommends that you always be able to maintain health so that your body's immune or immune system can stay better and stay strong. This library research aims to understand the urgency of health in Islam and maintain immunity in Islam. This study uses a descriptive method by describing the information in the relevant library materials. The data collection technique in this study is a documentary technique. Namely, information is extracted through documents from various library materials. It is analyzed using content analysis, namely, examining the object of discussion through analysis of books, essays, magazines, articles, and all forms of communication that can be analyzed. The results of this study indicate that the body's immunity or immunity in Islam is adequate rest, eating halal and good food and not excessive (in moderation), and regular exercise. Apart from adequate rest, adequate nutrition, and regular exercise. It is also recommended to maintain mental health, which of course, influences on increasing one's immunity or immunity by constantly reading the Qur'an, praying, and remembering Allah.
\end{abstract}

Keyword: Covid-19, maintaining immune, Islamic perspectives

\begin{abstract}
Abstrak: Penelitian ini tentang menjaga imunitas tubuh dari sudut pandang Islam pada saat pandemi. Kesehatan merupakan hal yang sangat diperhatikan dalam Islam, maka dari itu Islam menganjurkan agar selalu dapat menjaga kesehatan agar imun atau daya tahan tubuh dapat tetap baik dan tetapkuat. Penelitian kepustakaan ini bertujuan untuk memahami urgensi kesehatan dalam Islam dan menjaga imunitas dalam Islam. Penelitian ini menggunakan metode deskriptif dengan mendeskripsikan informasi-informasi dalam bahan pustaka yang relevan. Teknik pengumpulan data dalam penelitian ini adalah teknik dokumenter. Yakni, informasi digali melalui dokumen dari berbagai bahan pustaka setelah itu dianalisis dengan menggunakan analisis isi, yaitu mengkaji objek pembahasan melalui analisis buku, esai, majalah, artikel, dan segala bentuk komunikasi yang dapat dianalisis. Hasil penelitian ini menunjukkan bahwa imunitas atau kekebalan tubuh dalam Islam adalah istirahat yang cukup, makan makanan yang halal dan baik serta tidak berlebihan (secukupnya), dan olahraga yang teratur. Selain istirahat yang cukup, nutrisi yang cukup, dan olahraga yang teratur. Disarankan juga untuk menjaga kesehatan jiwa yang tentunya berpengaruh pada peningkatan imunitas atau kekebalan tubuh seseorang dengan cara senantiasa membaca Al-Qur'an, berdoa, dan berdzikir kepada Allah.
\end{abstract}

Kata Kunci: Covid-19, menjaga imunitas, perspektif Islam

\section{Introduction}

The past year, case of a pandemic has created anxiety in people's lives, because over time, the corona virus has increasingly spread and has caused many deaths in our country. The government has appealed to the public to always pay attention and maintain cleanliness by getting adequate rest, always washing hands, maintaining distance, and eating foods that contain vitamins and nutrients so that the immune system can be maintained in good condition. This matter is very meaningful, considering that corona 
virus sufferers who have successfully recovered are patients who have a good immune system and to get good immunity, it is very dependent on their own health, both physically and spiritually.

Islam is a very complex and perfect religion. In Islam, it takes care of all matters relating to human life, including in the health sector, in contrast to other religions. Islam pays close attention to health conditions, so that in the Qur'an and hadith there are many references to the importance of health, because health is one of the determining aspects for a person to carry out social activities. Like the saying that health is expensive. The human body and soul are both co-exist and both are always related and influence each other. A healthy body plays a role in getting mental health, and vice versa (Mustafa, 2004).

Herophilus $(323 \mathrm{BC})$ was a doctor, he said wisdom with the self cannot be realized if there is no health, art will not arise, power will disappear, wealth will be useless, and intelligence can no longer be practiced. In this case, being healthy is a very important thing so that a person can feel the pleasures of life. All worldly pleasures will be empty when health disappears, for example the pleasure of eating becomes tasteless, and sleeping does not feel comfortable, feeling anxious when someone is sick (Hasman, 2012).

Based on the description above regarding the importance of health, it can be understood that maintaining health is an important issue, especially during this pandemic. Because health has an impact on the implementation of worship rituals, especially for muslims. And if health is disturbed, both physically and spiritually, it will cause immunity or immortality of the body to be weak, and cause a person to be susceptible to disease so that pleasure cannot be enjoyed properly. Based on this, the author is motivated to research related to maintaining the body's immune from an Islamic perspective in a pandemic period.

\section{Materials and Methods}

This research is library research. This study uses qualitative data in the form of explanations, descriptions and writings sourced from references relevant to the research problem, both in the form of books, literature, articles, and journals. This study uses a descriptive method, which describes information from relevant library materials. Data collection technique in this research is a documentary technique, namely, information is extracted through documents from various library materials, after which it is analyzed using content analysis, namely examining human behavior or research objects indirectly but through analysis of books, essays, articles, and magazines as well as all forms of communication that can be analyzed. Based on this technique, qualitative data is compiled, grouping similar data, after that a critical analysis of its contents is carried out so that a concrete formulation is formulated and then explained in depth.

\section{Result and Discussion \\ A. Urgency of Health in Islam}

Islam is a religion that is very concerned with health. Because health is an indicator of the strength and weakness of a person's immune system, so with the sense that a healthy person means he is strong. The strength and weakness of people in carrying out worship is greatly influenced by their immune system or their health. People who have good health will have more power than people who are sick. Especially during the current pandemic which has had an impact on almost all countries including Indonesia. If this pandemic period continues, it will certainly have an impact on all sectors. For example in the education sector, the economy, politics, and also in the health aspect. Regarding health, it is the obligation of everyone to protect the health of themselves and others, by heeding health protocols for the realization of both physical and mental health so that they can have a good (strong) immune system.

Maintaining health in order to increase the body's immunity or immunity is an urgent matter in Islam, and Allah also loves strong believers more than weak believers. As the words of Rasulullah SAW as follows: 


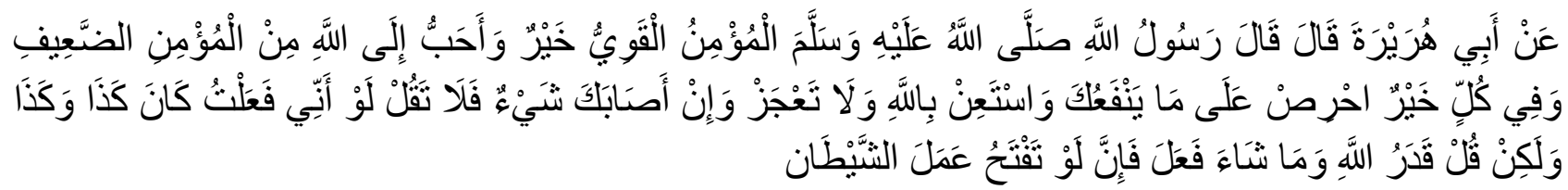

Meaning:

"From Abu Hurairah he said; "The Prophet sallallaahu 'alaibi wasallam said: 'A strong believer is better and more beloved to Allah Subhanahu wa Ta'ala than a weak believer. In each of them there is goodness, help Allah Azza wa Jalla and don't be a weak person. If you are afflicted with an accident, then don't say; 'If I had done this and that, surely it wouldn't have been like this and that'. But say; 'This is destiny. Allah and what He wills He will surely do, because indeed the expression of the word 'law' (if) will open the way for Satan's temptations" (Muslim No. 2664).

Based on the hadith, it can be understood that maintaining health in Islam is highly recommended, because basically a healthy person will be stronger than a sick person. In addition, people who are sick automatically affect the body's immune system, which of course greatly affects whether people are susceptible to disease or not. It is very clear in the description of the hadith above that it can be understood that Allah's love for his creatures is different, as his love for the strong believer is greater than his love for the weak believer. Because it cannot be denied that a strong believer has the energy to worship and has the potential to increase his worship.

How important is health in Islamic teachings so that it emphasizes to always be able to maintain health so that the body's immune can stay better and stay strong. Strong Muslims are not only able to protect themselves from being exposed to disease, but also strong Muslims can be a strength as well as preparation for maintaining religious integrity from various parties that have the potential to destroy Islam. Based on the word of Allah QS al-Anfal: 60.

Meaning:

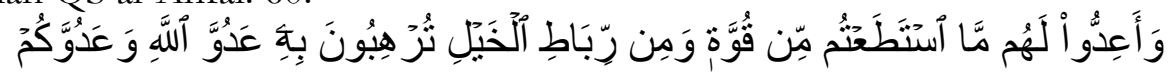

"And prepare against them (the disbelievers) whatever strength you can and from horses tethered for battle (by which) you frighten the enemies of Allah and your enemies" (QS al-Anfal: 60) (Kementerian Agama Republik Indonesia, 2018).

Apart from the arguments of the Qur'an that emphasize how important it is to maintain health, because healthy people, of course, their immune system will be stronger. The importance of maintaining health in Islam is also explained in a hadith of the Prophet Muhammad as follows:

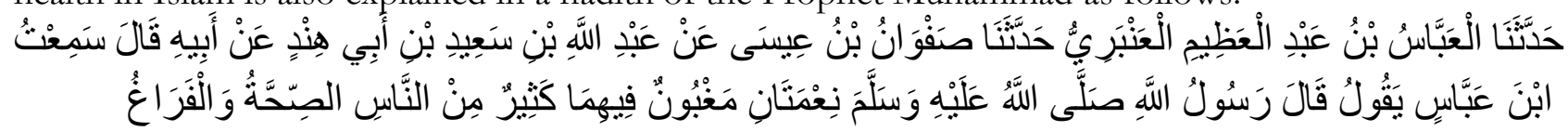

Meaning:

'Has told us Al'Abbas bin Abdul 'Azim Al'Anbari has told us Shafwan bin Isa from Abdullah bin Sa'id bin Abu Hind from his father he said; I heard Ibn Abbas say, "The Messenger of Allah -peace and prayer of Allah be upon himsaid: "Two pleasures that are often forgotten by most people are health and leisure" (Imam Ibnu Majah Kitab ke-32 No. 4160)

Based on the understanding of the hadith above, it is in accordance with the words of Ibnul Jauzi, namely that sometimes a person has a healthy body, but he does not have free time because he is more focused on his livelihood. Sometimes a person has free time but his body is not healthy. If a person has these two blessings (free time and a healthy body), then laziness dominates him in carrying out obedience to Allah; then he is the one who is deceived. Abdul Aziz explained that this is what often happens to the majority of people; they are deceived by free time and healthy pleasures, these two blessings pass without benefit (Bukhari, 182-184).

Based on the description of the arguments above, both the arguments from the Qur'an and the Hadith, it can be understood that maintaining health in Islam is very important, especially during the current pandemic. Because it is undeniable that during a pandemic, of course, a person should maintain 
their immune system or body immunity in order to minimize the possibility of contracting diseases such as the Covid 19 virus. A good (strong) immune system can only be owned by healthy people. Therefore, maintaining health is the same as maintaining the body's immune system. Therefore, maintaining the body's immunity or body immunity in Islam is of course as important as maintaining health.

\section{B. Efforts to Maintain Health in Islam}

Islam is a perfect religion, in which it regulates all aspects of human life, including those related to health conditions. The purpose of the revelation of the Shari'a in Islam is nothing but to bring benefit to humans and keep people away from harm. Islamic teachings contain commands and prohibitions. Every command that Allah swt. has set must provide great benefits for mankind when it is carried out. On the contrary, behind every prohibition of course there is a mafsadat (destruction) if humans do it (Saleh, 2020).

This is in accordance with the figh qaidah that:

Meaning:

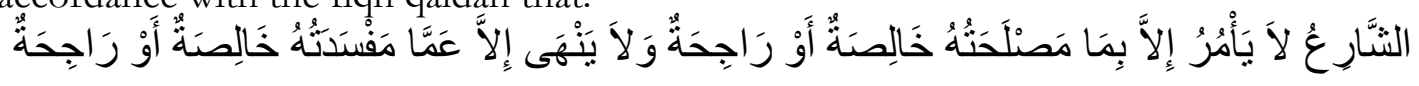

"Allah Subhanahu wa Ta'ala and His Messenger, does not command anything except that which is purely beneficial or the benefit is dominant. And it does not probibit anything except things that are really damaged or the damage is dominant"

Islam is a religion in which it always pays attention to the health of a person, especially for a Muslim. In view of the effects and dangers, it is important for everyone to pay more attention to health during this pandemic. The solution given by dr. Gia Pratama so that the risk of infection can be reduced by increasing the body's immunity. According to dr. Gia Pratama there are three pillars that affect the body's immunity or immunity. The three pillars in question are adequate rest, adequate nutrition and regular exercise. Regarding directions in fulfilling nutrition, starting from paying attention to what is often consumed. Like eating fruits and vegetables, and don't forget to drink enough water. In addition to maintaining good nutritional consumption, exercising regularly, and getting enough rest.

Observing the solution presented by dr. Gia Pratama related to the pillars that affect a person's immunity or immunity, it can be understood that the solution presented by dr. Gia Pratama is all contained in the teachings of Islam. Because if Muslims do all the teachings of Islam well, it will calm their souls and even heal their bodies and become a solution for them in carrying out their life together. Here are the tips contained in the teachings of Islam to maintain immunity:

a. Pay attention to drinks and food

Drinks and food are often things that most people don't pay attention to. There are so many people who are less concerned with what they consume, both in terms of how to get it or in terms of substances. Meanwhile, in matters of eating and drinking, Islam keeps a fairly serious concern. Because basically the food and drinks consumed directly affect the body, both physically and psychologically. Islamic teachings related to food always encourage the consumption of good and halal food (Elkarimah, 2016). As the word of Allah swt. In QS al-Baqarah: 168 as follows:

Meaning:

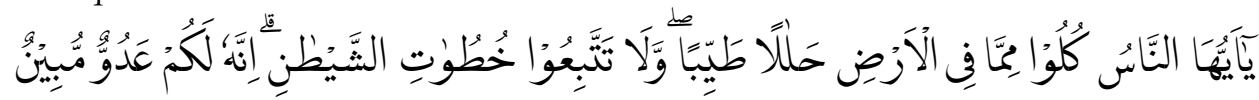

"O mankind, eat from whatever is on earth [that is] lawful and good and do not follow the footsteps of Satan. Indeed, he is to you a clear enemy" (Kementerian Agama Republik Indonesia, 2018).

Based on the meaning of the above verse, it can be understood that the call to determine good and halal food is intended for humans in general, not only for believers. What Allah commands is guaranteed to realize benefits in health, both physically and psychologically. In addition, the word thayyib is also understood as good food, in the sense that it has benefits for the body, not only halal. The quality of good and halal food referred to in the Qur'an requires Muslims to master the science of nutrition and protect the quality of eating thayyiban with the right method. Apart from being halal and good, in Islam it is also recommended not to overeat and drink. Based on the word of Allah in QS al-A raf 7: 31. 


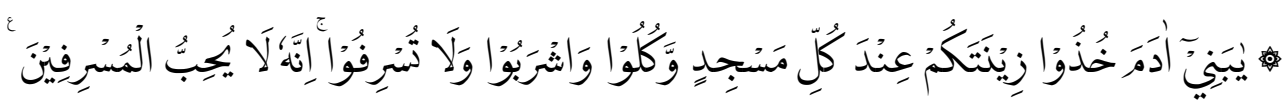

Meaning:

"O children of Adam, take your adornment at every masjid, and eat and drink, but be not excessive. Indeed, He likes not those who commit excess" (Kementerian Agama Republik Indonesia, 2018).

Based on the meaning of the verse above, it can be understood that in Islamic teachings related to clothing and food and drink, it is always recommended not to overdo it. Because basically Allah does not like people who are excessive. So in addition to the food we consume, it is halal and good, it also shouldn't be excessive.

b. Get enough rest

One of the efforts in maintaining immunity or immunity is adequate rest. Because after day of working for 7 hours, the body is at its lowest concentration and activity. If a person ignores sleep time, the muscle and nervous system will experience a decrease in ability. In Islam has been exemplified by the Prophet Muhammad with the habit of going to bed early and getting up early. Prophet Muhammad slept at the beginning of the night and in the middle of the second night, the Prophet Muhammad wake up. Usually, the Prophet Muhammad saw. wakes up and performs siwak, then performs ablution and prays until the time appointed by Allah. In addition to the habit of getting enough sleep at night, the Prophet Muhammad also had the habit of taking a short nap during the day. Doctor Ade Hashman, a doctor, in a book written with the title "Health Secrets of the Prophet" wrote that when before Zuhur, the Prophet had a habit of taking a short nap during the day. Sleep that gives satisfaction and comfort to the body that is burdened with fatigue and provides fitness for activities (Hafil, 2020). Sleep is also a sign of Allah's power as Allah says in QS ar-Rum: 23.

Meaning:

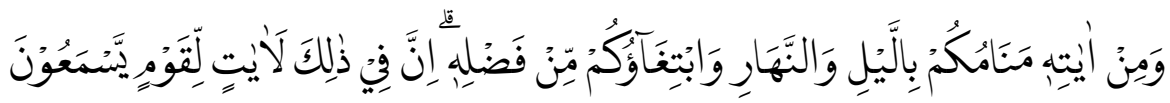

"And of His signs is your sleep by night and day and your seeking of His bounty. Indeed in that are signs for a people who listen" (Kementerian Agama Republik Indonesia, 2018).

Based on the meaning of the verse above, it can be understood that one of the signs of Allah's greatness is the sleep of a person at night and during the day. The verse above is interpreted by Abdur Rahman bin Nasir as'Sa'di saying that sleep is a form of Allah's grace. So from this description it can be understood that a person is recommended to rest at one time, namely at night, and scatter during the day to try to get the benefit of both this world and the hereafter. This has been exemplified by the Prophet Muhammad. that is enough rest by getting used to sleeping quickly at night and getting up in the middle of the night and taking a short nap, so the sleep of the Prophet Muhammad. In a day less than eight hours. Based on research conducted in the United States and Japan for 6 years with respondents aged $30-120$ years, the results showed that if people who usually sleep 8 hours a day have a faster risk of death and are very different from those who usually sleep 6-7 hours every day (Hafil, 2020).

c. Enough exercise

Sport is an activity that is very beneficial for physical fitness. The emphasis on the importance of exercise and its effects on the body was also conveyed by Ibn Qayyim. Exercise can strengthen and form the body's immunity against disease. As according to Muslim and Bukhari, the Messenger of Allah. Instructs parents to train their children in archery, horseback riding, and swimming (Hafil, 2020).

The view regarding the importance of sport was also emphasized by the next generations. For example, the instructions for teaching children to ride horses, swimming and sports were delivered by the caliph Umar. It is undeniable that exercise has a function to protect body fitness. A strong body is an immeasurable gift from Allah. This gift must always be protected as a form of gratitude. There are many ways to protect the body so that it always stays in shape, such as fulfilling adequate nutrition and balanced nutritional intake. Not only that, exercising is also a powerful way to boost immunity. With exercise, blood flow can be smooth and the body's metabolism is balanced. 
Exercise can make the body's immunity to be good so it can avoid disease. But apart from that, a strong body or physical fitness with continuous and regular exercise is very much needed in terms of selfdefense and self-preservation. Islam also advises to remain a strong person to establish themselves in jihad in the path of Allah swt. Because war is not just a battle of strategy, but also requires shrewdness in using weapons, horse agility, and archery skills. All of this can only be achieved through continuous practice, the ingredient is sports. Based on the word of God in QS al-Anfal/8: 60.

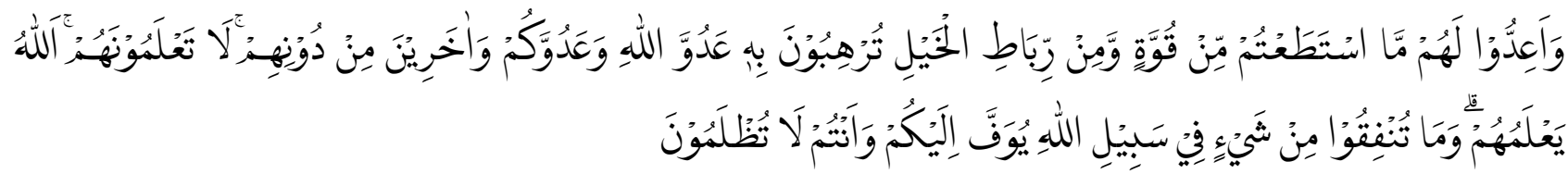

Meaning:

"And prepare against them whatever you are able of power and of steeds of war by which you may terrify the enemy of Allah and your enemy and others besides them whom you do not know [but] whom Allah knows. And whatever you spend in the cause of Allah will be fully repaid to you, and you will not be wronged" (Kementerian Agama Republik Indonesia, 2018).

d. Prayer, remembrance and reading Qur'an

The three pillars that have been offered by dr. Gia Pratama as a formula for maintaining good immunity, including: adequate rest, adequate nutrition and regular exercise. All of that has been contained in the recommendations of Islamic teachings in an effort to maintain health so that the body's immunity or immunity can remain good. However, apart from these three pillars, Islam also recommends always doing dhikr, praying and reading the Qur'an to calm one's soul as a form of effort to maintain mental health. Because mental health also has an influence on the body's immunity or a person's immune system. dr. H. Marzoeki Mahdi Psychiatrist from Bogor Hospital and dr. Lahargo Kembaren from Siloam Hospital Bogor, SPKJ explained that someone who is frustrated usually faces pressure that affects a person's mental condition, for example when someone is laid off from work. Mental stress during a pandemic occurs due to lack of attention, sleep problems, continuous fatigue. Or anxiety during a pandemic can occur because you often see high news and worries. With information every day related to the Corona Virus problem that does not end, so that fear arises. This worry raises a high sense of anxiety, difficulty relaxing, and easily emotional so that it can affect the state of his soul (Perhimpunan Dokter Spesialis Kedokteran Jiwa Indonesia, 2020). In Islam, it has been recommended to always perform prayers, remembrance and reading the Qur'an to calm one's soul as a form of effort to maintain mental health which basically will be able to affect one's immunity or immunity. The descriptions related to praying, remembrance and reading the Qur'an which are efforts to maintain peace of mind in Islam are as follows:

1. Prayers

Prayers that are done sincerely and accompanied by peace of mind can boost the immune system. Research results from an Islamic research body say that prayer can calm the soul which has an impact on the immune system, so that it can speed up recovery (Saleh, 2020). In addition, it has also been explained in the Qur'an, in order to always make prayer and patience as a helper. As Allah says in QS al-Baqarah: 45.

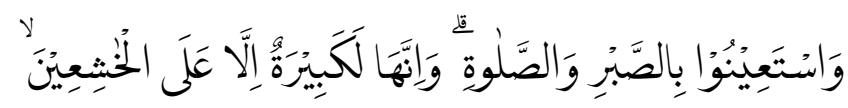

Meaning:

"And seek help through patience and prayer, and indeed, it is difficult except for the bumbly submissive [to Allab]" (Kementerian Agama Republik Indonesia, 2018).

Looking at the description above regarding prayer, it can be understood that prayer is one of the efforts to free people from the various problems they face, including during the pandemic. And prayer can also produce peace of mind that can have an impact on the body's immune system, so that it can accelerate healing, as the results of research conducted by the American Islamic Research Agency. 


\section{Reading the Quran}

Reading the Quran can calm the mind and heart, because people who read the Quran always remember and are close to the Creator. And those who always remember Allah, their hearts will be at peace. As Allah says in QS ar-Ra'd: 28.

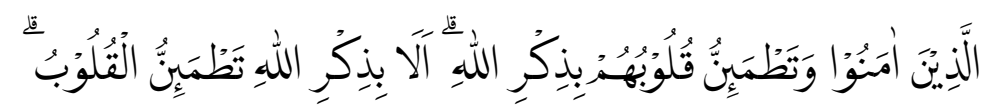

Meaning:

"Those who have believed and whose hearts are assured by the remembrance of Allah. Unquestionably, by the remembrance of Allab hearts are assured" (Kementerian Agama Republik Indonesia, 2018).

Based on the description above, it can be understood that reading the Qur'an is one of the best ways to increase immunity. This is reinforced by the results of research from Islamic medical experts in America on 210 patients voluntarily undergoing treatment accompanied by reading the Qur'an or listening to it for 48 treatments. The results obtained, $77 \%$ of a random sample consisting of Muslims and non-Muslims showed indications of relaxation of tense nerves and ultimately brought peace of mind. This will definitely increase the body's immunity.

3. Doing dhikr

Dhikr in Islam is usually understood by mentioning or remembering Allah verbally through good sentences (Sasongko, 2019). Dhikr solemnly to Allah SWT. will soothe the soul. And with a calm soul will appear strong body immunity (Saleh, 2020). Based on QS. Ar-Ra'd verse 28 which means, (ie) those who believe and their hearts find peace in the remembrance of Allah. Remember, only by remembering Allah does the heart find peace.

Based on the description above regarding efforts to maintain health in Islam, it can be understood that in Islam there are several tips for maintaining health, namely, adequate rest, eating moderately and having good and halal food and regular exercise. These three efforts are in nature to maintain health from the physical aspect, but in Islam, efforts to maintain health are by increasing immunity in addition to adequate rest, eating good and halal food and not overdoing it (in moderation) and exercising regularly. It is also recommended to maintain mental health which of course has an influence on increasing immunity or a person. Efforts to maintain mental health, Islam recommends several things, namely, reading the Qur'an, praying and dhikr (remembrance of Allah). From this description it is clear that Islam is quite complete in managing all aspects of a person's life, including in terms of maintaining health, especially during this pandemic.

\section{Conclusion}

Health is an urgent matter in Islam, so it always conveys the meaning of health in life to its people. People who have good health will have better strength than those who are less healthy, especially during the current covid 19 pandemic which has impacted almost all countries including Indonesia. Efforts to maintain health in Islam, in general, there are two types, namely, how to maintain health in physical and mental aspects. Maintaining health in the physical aspect of course with adequate rest, eating in moderation and consuming good and halal food, as well as with regular exercise. As for maintaining mental health, namely by reading the Qur'an, praying and dhikr (remembrance of Allah). These three things (reading the Qur'an, praying and dhikr) can create peace of mind for a person which of course has an influence on increasing immunity.

\section{References}

Akbar, D. L., \& Budiyanto. 2020. Konsep kesehatan dalam al-Qur'an dan hadis. Al Bayan: Jurnal Ilmu Al Qur'an dan Hadist 3(2): 153-173

Elkarimah, M. F. 2016. Kajian al-Quran dan Hadits tentang Kesehatan. Tajdid 15(1): 105-126.

Firman. 2021. "Sehatlah, karena Mukmin Kuat Lebih Dicintai Allah." HidayatullahMakassar.id. January, 02.

Hadits Imam Ibnu Majah Kitab ke-32, Bab Hikmah, hadits No. 4160.

Hafil, M. 2020. "Cara Nabi Muhammad Menjaga Daya Tahan Tubuh.” Republika. March, 18.

Hashman, A., \& W. Widodo. 2012. Rahasia Kesehatan Rosulullab: Meneladani Gaya Hidup Sehat Islami Nabi Muhammad SAW. Jakarta: Noura Book.

Kementerian Agama Republik Indonesia. 2018. Al-Quran dan Terjemahannya. Bandung: PT. Dinamika Cahaya Pustaka. 
Lestari, P. A. 2020. Kematangan beragama dalam masa pandemi Covid-19: Telaah sosiologis atas nasihat Imam Besar Istiqlal Nasaruddin Umar. The Sociology of Islam 1(1): 165-180.

Mush'ab M, M., U. H. Salsabila., A. D. M. Hanindraswari., A. A-Syadza., \& V. Sarika. Menjaga kesehatan mental di tengah pandemi Covid-19 melalui Tazkiyatun Nafs. Jurnal WARAQAT 5(2): 99-110.

Putra, A. P. 2020. "Mengenal Sistem Imunitas Tubuh." Pahamify. March, 26.

Saleh, A .M. 2020. "Solusi Islam dalam Meningkatkan Imunitas Tubuh.” NusaDaily.com. June 18.

Sari, M., \& Asmendri. 2020. Penelitian kepustakaan (Library Research) dalam penelitian Pendidikan IPA. Natural Science: Jurnal Penelitian Bidang IP A dan Pendidikan IPA 6(1): 41-53.

Zed, M. 2014. Metode Penelitian Kepustakaan, Ed. III. Jakarta: Pustaka Obor Indonesia. 